\title{
Freedom and Federalism: The First Amendment's Protection of Legislative Voting
}

\author{
Steven N. Sherr
}

Public discussions of public issues, together with the spreading of information and opinion bearing on those issues, must have a freedom unabridged by our agents. Though they govern us, we, in a deeper sense, govern them. Over our governing, they have no power. Over their governing we have sovereign power.

Alexander Meiklejohn ${ }^{1}$

\section{INTRODUCTION}

The ideal of popular sovereignty inspired the creation of the American Republic. ${ }^{2}$ In an ideal republican government, elected representatives express and implement the people's will through legislative speech and activities. However, an elected legislator's ability to perform these representative functions depends largely upon her ability to speak freely and to make independent choices. In short, republican government requires legislative independence. ${ }^{3}$ It follows that constraints on independent legislative speech or voting undermine the legislature's representative function.

As an institutional approximation of the republican ideal, the American constitutional system depends upon legislative independence for sustenance and legitimacy. American legislatures, the political institutions most responsive to the public due to regular and frequent elections, supposedly infuse the people's will into the machinery of government. As institutions designed to facilitate decision through debate, legislatures channel rich public debate into effective democratic self-government. As a result, more than any other institution of republican government, legislatures thrive when debate inside their walls is

1. Alexander Meiklejohn, The First Amendment Is an Absolute, 1961 SUP. CT. REV. 245, 257.

2. The Preamble's invocation of "We the People" exercising the power to establish the Constitution demonstrates the Founders' rhetorical commitment to the doctrine of popular sovereignty. See also GoRDON S. WOOD, THE CREATION OF THE AMERICAN REPUBLIC 1776-1787, at 344-89 (1969).

3. This Note uses the terms "legislative independence" and "legislative freedom" interchangeably to describe a state of affairs wherein legislators are free to represent the interests of constituents without undue interference from the executive branch or other nonjudicial governmental entities. 
"uninhibited, robust, and wide-open." Conversely, coercion of legislative activity-especially voting, by the executive branch or a superior level of government, such as Congress-threatens the constitutional function of legislatures by distorting debate and undermining their capacity to represent the true sovereign, the people.

Until recently, legal protection of legislative independence rested exclusively on the United States Constitution's Speech or Debate Clause, ${ }^{5}$ similar state constitutional provisions, ${ }^{6}$ and common law notions of legislative immunity. Stepping beyond these traditional notions of legislative immunity, however, three recent federal decisions have concluded that the First Amendment ${ }^{7}$ provides a separate constitutional safeguard for the uniquely expressive act of legislative voting. ${ }^{8}$ This Note agrees with their conclusion and further argues that federal statutes that condition funding for states on the enactment of particular legislation should trigger First Amendment scrutiny. ${ }^{9}$

Part I explores traditional constitutional and common law foundations for protecting legislative speech and voting. Part II summarizes the major issues presented in Clarke v. United States, which is the first federal decision to find a federal conditional spending measure invalid because it violated legislators' First Amendment rights. ${ }^{10}$ Finally, Part III examines the scope of the First Amendment's protection of legislative voting and suggests that courts can use traditional First Amendment balancing tests to weigh governmental interests in imposing particular conditions on states against the interests of free expression and rich public debate in state and local legislatures.

4. New York Times v. Sullivan, 376 U.S. 254, 270 (1964). While not referring to legislative speech in particular, the Court, per Justice Brennan, declared that the First Amendment requires the Court to evaluate restrictions on expression "against the background of a profound national commitment to the principle that debate on public issues should be uninhibited, robust, and wide-open." Id.

5. U.S. CONST. art. I, \& 6 ("[F]or any Speech or Debate in either House, [the Senators and Representatives] shall not be questioned in any other Place.").

6. See infra note 18 and accompanying text.

7. U.S. Const. amend. I ("Congress shall make no law ... abridging the freedom of speech ....").

8. Clarke v. United States, 886 F.2d 404 (D.C. Cir. 1989), vacated as moot, 915 F.2d 699 (D.C. Cir. 1990) (en banc); Miller v. Town of Hull, 878 F.2d 523 (1st Cir.), cert. denied, 110 S. Ct. 501 (1989); Wrzeski v. City of Madison, 558 F. Supp. 664 (W.D. Wis. 1983).

9. Examples of federal funding conditioned on state legislative action abound. See, e.g., 23 U.S.C. $\$ 131$ (b) (1990) (conditioning $10 \%$ of federal highway funds on a state's adopting federal standards governing the control of outdoor advertising along federal interstates and primary highways); 23 U.S.C. $\$ 158(a)$ (1990) (conditioning 5\% of federal highway funds on state's adoption of national minimum drinking age); 42 U.S.C. $\$ 602(a)(3)$ (1983) (conditioning federal funds for Aid for Families with Dependent Children on state establishing or designating a "single State agency" to supervise administration of the plan); and 49 U.S.C. $\& 1609$ (1976) (conditioning federal loans and grants in support of any state's urban mass transit construction projects upon state's adoption of federally-prescribed labor standards to govern projects).

10. Clarke v. United States, 886 F.2d 404 (D.C. Cir. 1989), vacated as moot, 915 F.2d 699 (D.C. Cir. 1990) (en banc). The full Court of Appeals vacated Clarke because the appropriation statute which the threejudge panel of Court of Appeals invalidated on First Amendment grounds lapsed prior to the full court's rehearing of the case. 915 F.2d 699, 700 (D.C. Cir. 1990) (en banc), vacating as moot, 886 F.2d 404 (D.C. Cir. 1989). Thus, the full court vacated Clarke for reasons completely unrelated to the First Amendment issues raised by the panel decision. Accordingly, this Note relies on Clarke solely for its reasoning and not for its legal significance. 


\section{FOUNDATIONS FoR the PROTECTION OF Legislative SPEECH AND Voting: SEPARATION OF POWERS, FEDERALISM, AND SELF-GOVERNMENT}

Although the notion that the First Amendment protects legislative voting has only limited precedential support, ${ }^{11}$ it comports with well-established principles of legislative independence. The scarcity of precedent affording First Amendment protection for legislative voting initially discourages adoption of a doctrine allowing judicial review of conditional spending measures that give Congress substantial leverage over the states. ${ }^{12}$ However, as discussed below, shielding state legislators from congressionally-imposed liability actually reinforces the Constitution's preservation of state legislators as political counterbalances to the national government and as prolocutors of the people's will. Also, a review of more traditional forms of legislative immunity will demonstrate that constitutional and common law protections of legislative independence have already strengthened the separation of powers and the structure of federalism in the American system. Specifically, the Speech or Debate Clause of the U.S. Constitution and similar provisions in many state constitutions help maintain the separation of powers between legislative and executive branches in both federal and state governments.

\section{A. Speech or Debate Clause: Separation of Powers and the Scope of Legislative Immunity}

The Founding Fathers considered freedom of speech in the national legislature integral to the maintenance of a republican government. ${ }^{13}$ Following England's lead, ${ }^{14}$ they considered legislative independence from the coercive powers of the executive a necessary component of the separation of powers

11. Clarke cited only two cases for the direct proposition that the First Amendment protects legislative voting. 886 F.2d at 411-12 (citing Miller, 878 F.2d 523 (Town Board of Selectmen's removal of elected members of Hull Redevelopment Authority, because of Authority's disagreement over whether to approve subsidized housing project, violated Authority members' First Amendment rights); Wrzeski, 558 F. Supp. 664 (city council member's First Amendment rights abridged by city ordinance subjecting her to censure and fines if she chose to abstain from voting on any question put before the city council)).

12. Indeed one of the factors weighing in the D.C. Circuit's decision to vacate the panel opinion in Clarke was "avoidance" of a "gratuitous conflict with a co-equal branch of government." 915 F.2d at 708.

13. Kilbourn v. Thompson, 103 U.S. 168, 202-03 (1880); see also James Wilson, Of the Legislative Department, in 2 THE WORKS OF JAMES WILSON 3, 37-38 (James D. Andrews ed., 1896).

14. American legislative immunity evolved from British parliamentary privilege. The English Bill of Rights provided: "That the freedom of speech, and debates or proceedings in parliament, ought not to be impeached or questioned in any court or place out of parliament." An Act for Declaring the Rights and Liberties of the Subject, and Settling the Succession of the Crown, 1 W. \& M. ch. 36, $\$ 9$ (1689). The Supreme Court also has noted that from its origins in the conflicts between the House of Commons and the British Crown, legislative immunity has existed primarily to protect legislative institutional independence from executive coercion, rather than as a personal right to protect individual legislators from royal penalties. United States v. Brewster, 408 U.S. 501, 507 (1972). 
which comprised the structural core of the new constitutional system. ${ }^{15}$ Thus, in order to shield the deliberative process within Congress from interference by the executive branch, the Founders drafted the Speech or Debate Clause of the U.S. Constitution. ${ }^{16}$ Indeed, the fundamental purpose of the Speech or Debate Clause is "freeing the legislator from executive and judicial oversight that realistically threatens to control his conduct as a legislator."17

The fact that the constitutions of every state except Florida and North Carolina provide some form of protection for legislators underscores this national commitment to legislative independence. ${ }^{18}$ Massachusetts may have the most acclaimed state legislative immunity provision because the earliest and most famous interpretation of such a provision appeared in that state's 1808 case of Coffin v. Coffin. ${ }^{19}$ The Coffin opinion, often cited for establishing the parameters of legislative immunity, ${ }^{20}$ specifically included "the giving of a vote" as one of the representative functions protected under the state's immunity clause. ${ }^{21}$

Although it is a state court's interpretation of a state constitution's legislative immunity provision, Chief Justice Parson's Coffin opinion, written "so early after the formation of the Federal Constitution,"22 has influenced nearly all subsequent interpretations of the U.S. Constitution's Speech or Debate Clause. Not surprisingly, when the U.S. Supreme Court addressed the Constitution's Speech or Debate Clause for the first time in Kilbourn v. Thompson, ${ }^{23}$ it adopted a relatively broad view of legislative immunity which included the votes of legislators. ${ }^{24}$ While some Supreme Court decisions have since propounded a more restrictive view of the Clause than expressed in Coffin and

15. United States v. Johnson, 383 U.S. 169, 178 (1966); see also Alexander J. Cella, The Doctrine of Legislative Privilege of Speech or Debate: The New Interpretation as a Threat to Legislative Coequality, 8 SUFFOLK U. L. REv. 1019, 1067-70 (1974); Robert J. Reinstein \& Harvey A. Silverglate, Legislative Privilege and the Separation of Powers, 86 HARV. L. REV. 1113, 1120-40 (1973).

16. U.S. CONST, art. I, §6.

17. Gravel v. United States, 408 U.S. 606,618 (1972).

18. The constitutions of 48 states contain some form of legislative immunity provision. Thirty-nine of these provisions specifically shield "speech" and/or "debate" in the legislature. The immunity provisions of seven states (Arizona, Arkansas, Connecticut, Iowa, Mississippi, Nevada, and Texas) do not mention "speech" or "debate," but immunize legislators from arrest while the legislature is in session. California's constitution provides immunity from "civil process" during a session of the legislature. CAL. CONST. art. IV, $\$ 14$. And South Carolina's constitution protects legislators in their "persons and estates." S.C. CoNST. art. III, § 14 .

19. 4 Mass. 1 (1808).

20. See, e.g., Nixon v. Administrator of Gen. Servs. 433 U.S. 425, 515 (1977) (Burger, C.J., dissenting); Gravel v. United States, 408 U.S. 606, 660 (1972) (Brennan, J., dissenting).

21. 4 Mass. at 27.

22. Kilbourn v. Thompson, 103 U.S. 168, 204 (1880).

23. $I d$.

24. But cf. Cella, supra note 15, at 1053-67 (arguing that Kilbourn was overly restrictive of Congress' powers). 
Kilbourn, ${ }^{25}$ no court has questioned the inclusion of legislative voting as an activity protected by the Speech or Debate Clause. ${ }^{26}$

Thus, from the early days of the Republic, courts have recognized that the Speech or Debate Clause and state constitutional legislative immunity provisions are integral to the separation of powers. Courts have also consistently interpreted these provisions to include voting within the scope of protected legislative activity.

\section{B. Tenney v. Brandhove: Legislative Immunity and Federalism}

While Coffin and Kilbourn explain how legislative immunity reinforces the separation of powers, the Supreme Court's extension of the federal immunity doctrine to state legislators in Tenney v. Brandhove ${ }^{27}$ has important federalism implications. In Tenney, the Court found that the California State Senate FactFinding Committee on Un-American Activities (the "Tenney Committee") and its individual members were not civilly liable for alleged violations of Brandhove's civil liberties resulting from his compelled appearance before the Committee. ${ }^{28}$ Framing its holding as a rule of statutory construction, the Court determined that federal common law legislative immunity limited Congress' authority to make state legislators answerable in causes of action based on federal statutes. In enacting the Reconstruction Era civil rights statutes under which Brandhove sued, Congress may not have had the power to impinge on the common law tradition of "legislative freedom achieved in England by Civil War and carefully preserved in the formation of State and National Governments here ...."29 Furthermore, the Court held that even claims that a state legislature acted with an "unworthy purpose" do not destroy the legislative privilege which exists for the "public good." 30 This result comports with the historically expansive reading of legislative immunity established by the Speech or Debate Clause. Since the Tenney Committee's investigation of Brandhove fell within "the bounds of legislative power" and did not usurp "functions

25. See, e.g., United States v. Brewster, 408 U.S. 501, 512 (1972); Gravel v. United States, 408 U.S. 606,625 (1972).

26. Indeed, the Supreme Court has consistently stated that the Speech or Debate Clause protects legislative voting. See, e.g., Doe v. McMillan, 412 U.S. 306, 311-12 (1973); Gravel, 408 U.S. at 617; Powell v. McCormack, 395 U.S. 486, 502 (1969).

27. 341 U.S. 367 (1951).

28. Brandhove claimed that his civil liberties guaranteed under the Fourteenth Amendment, and enforced under 8 U.S.C. \& 43 (current version at 42 U.S.C. \$ 1983 (1989)) and 8 U.S.C. \$ 47(3) (current version at 42 U.S.C. $\$ 1985(3)(1989)$ ), were violated because the hearing he was required to attend " was not held for a legislative purpose,' but was designed to intimidate and silence [Brandhove] and deter and prevent him from effectively exercising his constitutional rights ...." Tenney, 341 U.S. at 371 (1951) (quoting Brandhove v. Tenney, 183 F.2d 121, 122-23 (9th Cir. 1950)).

29. 341 U.S. at 376. But cf. Jobson v. Henne, 355 F.2d 129, 133 n.10 (2d Cir. 1966) (legislative immunity from claims under 42 U.S.C. $\$ 1983$ does not extend to state administrative officials).

30. 341 U.S. at 377. 
exclusively vested in the Judiciary or the Executive," the Committee could "assert a right to call [Brandhove] before it and examine him."31

Although Tenney did not alter the scope of activities covered by legislative immunity, it transformed the doctrine of legislative immunity from a rule reinforcing the separation of powers into a principle of federalism. For the purposes of this Note, Tenney's extension of the federal immunity doctrine to state legislators established a common law predicate for the notion that the federal rights enshrined in the First Amendment might also shield state and local legislative activities from congressional encroachments.

To be sure, a constitutionally enforceable legislative privilege would buttress the role of state legislatures and state legislators as independent sources of political power in the federal system. Such a result, however, is not radical. The notion that the "legislative" activities of popularly elected state legislators enjoy legal protection against federal intrusion has both constitutional and historical support.

From the early years of the American Republic, state governments provided a structural counterbalance to the federal government. This structural role manifested itself prominently in constitutional provisions specifically crafted to ensure significant state influence in national policy decisions. ${ }^{32}$ Indeed, Virginia and Kentucky's defiant response to the Federalist central government's adoption of the Alien and Sedition Acts demonstrates the capacity of independent state legislatures to act as defenders of political liberty against a selfinterested national government and graphically illustrates the importance of state legislative immunity from federal intrusion. ${ }^{33}$

In this spirit, the holding in Tenney confirms the importance of independent state governments in the federal system. If not limited by legislative immunity, federal statutes such as those in Tenney threaten to impose civil liability on individual state legislators and thus to deter them from the independent exercise of their representative functions. Furthermore, if state governments are to perform their unique political function in the federal system, state legislators must not feel constrained by congressional attempts to control their legislative activities. Thus, Tenney's finding of federal common law legislative immunity, while derived from the U.S. Constitution's Speech or Debate Clause, a separation of powers mechanism, ultimately prescribes a common law rule of federal-

31. Id. at 378 .

32. In addition to the states' role in electing the President under the electoral college system (U.S. CONST. art. II, $\$ 1$ ), their status in the structure of the Senate (U.S. CONST. art. I, $\$ 3$ ), and their role in amending the Constitution (U.S. CONST. art. V), states retain powers under the Tenth Amendment. U.S. CONST. amend. X ("The powers not delegated to the United States by the Constitution, nor prohibited by it to the States, are reserved to the States respectively, or to the people.").

33. Akhil R. Amar, The Bill of Rights as a Constitution, 100 YALE L.J. 1131, 1135 (1987) (applauding Virginia and Kentucky Resolutions of 1798-1800 for fusing the "rhetoric of federalism and freedom" while "sounding the alarm when [state legislators] saw the central government taking actions that they deemed dangerous and unconstitutional"). 
ism that limits the power of the federal government over the activities of state legislators. ${ }^{34}$

\section{Free Speech: Legislative Immunity and Popular Sovereignty}

While Tenney derives a common law rule of federalism from the Speech or Debate Clause, it also reaffirms the centrality of legislative immunity to representative government. ${ }^{35}$ Under both the Speech or Debate Clause and common law legislative immunity, legislators are the immediate beneficiaries of broad speech and voting freedoms designed to facilitate uninhibited debate and decisionmaking. Yet these freedoms are more than mere privileges for individual legislators. Fundamentally, they protect the entire polity's right to democratic self-government. In this sense, the function of legislative immunity

34. It is important, however, not to overread Tenney. Justice Black's concurrence in Tenney is significant for its clarification of what the Court did not hold in its opinion. While individual legislators enjoy broad personal immunity for their actions, the constitutional validity of legislative action is not coextensive with this immunity. 341 U.S. 367, 379 (1951) (Black, J., concurring). While the Court held that Brandhove could not sue the Tenney Committee and its members under the federal civil rights statutes, it does not follow that the Tenney Committee's persecution of Brandhove was legal. If the Committee proceeded to fine or imprison him on perjury, contempt, or other charges, Brandhove could have defended himself on the grounds that the resolution creating the Committee or the Committee's actions under it were "unconstitutional and void." Id. at 380 . However, such action was not at issue before the Court and thus the Committee's inquisition of Brandhove did not, in the majority's view, violate Brandhove's constitutional rights. This limitation on Tenney also limits the conclusions of this Note. This Note concludes that the First Amendment shields legislative speech and activities from certain federal intrusions. However, in the case of a state legislature violating the individual rights and freedoms guaranteed under the Fourteenth Amendment, this Note does not argue that a First Amendment defense can prevent vigorous federal enforcement of those Fourteenth Amendment guarantees.

A related question was raised in the "Yonkers" case, Spallone v. United States, 110 S. Ct. 625 (1990). In Spallone, the Supreme Court found that the district court's imposition of sanctions against individual council members, as opposed to sanctions against the city as a whole, exceeded the discretionary power of the court to enforce a consent decree in a statutory and constitutional civil rights case. Id. at 634-35. This raises an important question for this Note, which argues that First Amendment scrutiny is triggered when Congress conditions federal funding on states enacting prescribed legislation.

A broad reading of the dicta in Spallone might suggest that only threats of personal fines levied against individual legislators, as opposed to the legislative body as a whole, can trigger constitutional review. There are at least two reasons why Spallone should not be read in this way. First, Spallone is not a First Amendment opinion. While the Yonkers legislators contended that the district court's orders violated their right to freedom of speech under the First Amendment, the Court did not find it necessary to rule on that question because the orders were an abuse of discretion under "traditional equitable principles." Id. at 631 . As a result, Spallone should not be read as limiting First Amendment protection of legislative voting to circumstances in which individual legislators face fines or penalties. This Note, on the other hand, argues that First Amendment scrutiny can be triggered by congressionally imposed burdens on states and localities if such burdens necessarily contemplate legislators voting a certain way. Second, in Spallone the district court was attempting to enforce a consent decree. Unlike states compelled to accept a condition, parties to a consent decree agree to its terms. Therefore, the analogy between compelled expression in the conditional spending cases and the elective nature of a consent decree is quite attenuated.

35. In Tenney, Justice Frankfurter wrote: "It is significant that legislative freedom was so carefully protected by constitutional framers at a time when Jefferson expressed fear of legislative excess . . . . For the loyalist executive and judiciary had been deposed, and the legislature was supreme in most States during and after the Revolution." 341 U.S. at 375 (citations omitted). 
mirrors that of the First Amendment in society at large: to protect and promote an essential mechanism of democracy-"rich public debate." 36

However, rich public debate represents only the means, not the ends, of democratic self-government. A properly functioning democracy often requires certain limitations on legislative immunity and freedom of speech to ensure that these freedoms facilitate, rather than inhibit, rich public debate and democratic self-government. Liberated but not lawless, legislators and ordinary citizens alike must abide by regulations to ensure that louder or more pervasive speakers do not "drown out" others and to guarantee that discourse does not devolve into chaos. ${ }^{37}$

\section{Popular Sovereignty and Freedom of Speech: The Legislature's Representational Link to the Polity}

Freedom of speech and popular sovereignty are inextricably linked. While a people may possess some of the trappings of democratic self-government, such as the right to elect representatives and to vote on matters of public concern, a people can never truly be sovereign without freedom of speech. Specifically, the ability to freely and knowledgeably discuss and debate matters of public concern is a critical component of democratic decisionmaking. Conversely, the abridgment of free debate and discussion undermines the people's ability to govern themselves.

In the American constitutional system, sovereignty ultimately resides with the people. Prior to ratification of the Constitution, the colonists formed state governments to act as agents of their will. With ratification of the Constitution, the people of the newly formed nation delegated additional powers to another set of agents in the national government. Significantly, however, the Ninth ${ }^{38}$ and Tenth Amendments reserved all powers not delegated to the national government for both the people and the states. The power to elect representatives and the power, by a supermajority of state legislatures, to amend the Constitution are prominent among these reserved powers. Thus, while the national government became, in many respects, the primary implementor of the people's will, the people retained the ultimate power to govern themselves.

36. The phrase "rich public debate" is borrowed from Owen Fiss. It connotes a state of affairs wherein issues of public concern receive "full and fair consideration." Owen M. Fiss, Free Speech and Sacial Structure, 71 IOWA L. REV. 1405, 1410 (1986). Fiss argues that "rich public debate," like Meiklejohn's "freedom of speech," infra text accompanying notes 39-44, is a vital component of democratic self-government.

37. See, e.g., Bellotti v. First Nat'l Bank of Boston, 435 U.S. 765, 802 (1977) (White, J., dissenting). Justice White's dissent in Bellotti is an eloquent defense of a restriction on individual speech in the form of campaign spending limits. By making room for less pervasive voices the spending limits enhanced public discourse regarding a ballot measure in Massachusetts. See also Owen M. Fiss, Why the State?, 100 HARV. L. REV. 781 (1987).

38. U.S. CONST, amend. IX ("The enumeration in the Constitution, of certain rights, shall not be construed to deny or disparage others retained by the people."). 
Although the Ninth and Tenth Amendments nominally reserved the people's ultimate governing authority, it was the First Amendment's protection of the freedom of speech that, in reality, empowered the people to govern themselves. Alexander Meiklejohn has explained that the protection of the freedom of speech constitutes a general guarantee of political liberty and democratic selfgovernment. ${ }^{39}$

In Meiklejohn's view, voting constitutes "the official expression of a selfgoverning man's judgment on issues of public policy." theory, free speech and debate are integral components of the freedom to vote. Consequently, no government official may abridge the people's right to free speech and debate on issues of public concern without infringing on selfgovernment. Elected or not, these government officials are no more than "subordinate agen[t]s" of the people. ${ }^{41}$ Therefore, attempts by these agents to stifle freedom of speech inevitably undermines the people's right to govern themselves.

While governmental noninterference with free speech and debate is a condition precedent to Meiklejohn's conception of democratic self-government, its realization requires significantly more than the government simply leaving voters alone. Only if voters can expose themselves to the wide range of human communications from which they can derive "knowledge, intelligence [and] sensitivity to human values," will they obtain the capacity for "sane and objective judgment which, so far as possible, a ballot should express." "Within this "wide range of communications," Meiklejohn specifically included "education, in all its phases," "the achievements of philosophy and the sciences," "literature and the arts," and public discourse on policy issues. ${ }^{43}$ Each of these "communications," according to Meiklejohn, is worthy of First Amendment protection. ${ }^{44}$

It follows from Meiklejohn's analysis that the legislature's dependence on free speech for democratic viability is based on three factors. First, truly representative decisionmaking in the legislature depends on robust and informed public debate to elicit the myriad viewpoints comprising the will of the people. Second, discourse within the chamber must be uninhibited, permitting the legislature to grapple with all relevant viewpoints and, thereby, to reach decisions that reflect the will of the people. Finally, because legislators are also "speakers," their debates, pronouncements, edicts, and activities all become part of the ongoing dialogue between the people and their agents in government. In this way, freedom of speech inside the legislature completes a continuous

39. Meiklejohn, supra note 1 .

40. Id. at 256.

41. Id.

42. Id.

43. Id. at 257.

44. Id. 
cycle in which the people express preferences to their legislators, legislators "translate" these preferences into legislative speech and other communicative activities, and legislators communicate these "translations" to the people through their voting records. These legislative communications, in turn, enrich the public discourse and, ultimately, help voters form preferences for candidates. ${ }^{45}$

The rationale behind a legal rule protecting legislators' utterances argues pointedly for affording similar protections to legislative voting. The Clarke court embraced the notion that votes help inform the electorate: " $[\mathrm{A}]$ legislator's voting record is 'the best indication of [his or her] position on specific issues and his or her ideological persuasions." "46 Critics might argue that in reality legislative "logrolling" and other internal "vote exchanges" distort the linkage between a legislator's duty to discharge his understanding of public preferences and a particular instance of vote casting ${ }^{47}$ Presumably, however, a voter's image of her legislator will be shaped by the entire voting record, where the larger sample will correct for occasional deviations from the legislator's actual understanding of public preferences ${ }^{48}$ Moreover, it is possible that the exchange of votes within a legislature does not significantly threaten the representational linkage between legislators and constituents. In return for voting as his colleague prefers, a shrewd legislator is likely to increase his own effectiveness at promoting the interests of his constituents in subsequent matters.

In addition to providing a powerful index by which voters may ascertain a legislator's position, the actual casting of a legislative vote is a unique statement of preference. ${ }^{49} \mathrm{It}$ is a form of expression distinct from other forms in the legislative process. Precisely because it channels preferences into the triad of "aye," "nay," and "abstain," legislative voting is a powerful mode of collective expression. Also, under majoritarian rules, the prevailing position on any question put to a vote is an additional form of expression of preference by the entire body of the people's representatives. ${ }^{50}$ Thus, both collectively and individually, legislators' votes, as much as speech in the chamber, are part of the stream of information that makes up public discourse in a democracy.

45. Bond v. Floyd, 385 U.S. 116, 136-37 (1966).

46. Clarke v. United States, 886 F.2d 404, 411 (D.C. Cir. 1989), vacated as moot, 915 F.2d 699 (D.C. Cir. 1990) (en banc) (quoting MICHAEL BARONE \& GRANT UJIFUSA, THE ALMANAC OF AMERICAN POLITICS 1988, at xviii (1988)).

47. Concern about the counterrepresentational effect of logrolling inspired inclusion of the following promise in the oath that members of the Mississippi state legislature must take: "I will not vote for any measure or person because of a promise of any other member of this legislature to vote for any measure or person, or as a means of influencing him or them so to do. So help me God." MISS. CoNST. art. IV, $\$ 40$.

48. See generally POLTICS IN AMERICA: THE 100TH CONGRESS (Alan Ehrenhalt ed., 1987) (biennial compilation of profiles, votes and interest group ratings of individual members of Congress).

49. See infra notes $91-97$ and accompanying text.

50. Hutchinson v. Proxmire, 443 U.S. 111, 133 (1979) ("Voting and preparing committee reports are the individual and collective expressions of opinion within the legislative process."). 


\section{Valid Limitations on Legislative Speech and Voting}

While representative government may require broad freedom of speech for legislators, competing considerations may limit this freedom. Obviously, legislative immunity does not apply to illegal or unconstitutional legislative action. ${ }^{51}$ Similarly, people who serve as legislators, when acting legally, yet "outside the sphere of legitimate legislative activity," are not immune to civil liabilities stemming from their nonlegislative speech or activities. ${ }^{52}$

On the other hand, legislative procedures that restrict speech to help resolve debate and expedite decision, such as time limitations on floor debates, usually pass judicial scrutiny because of the public interest in an efficient lawmaking process. As a result, courts have generally upheld internal rules to limit debate on a question ${ }^{53}$ or to allocate legislative committee assignments in such a way as to distribute power unevenly within the legislature..$^{54}$

Finally, as Part III of this Note suggests, even if the First Amendment protects legislative voting, Congress could justify restrictions on state legislative voting in the form of a conditional spending measure by demonstrating either a "substantial" or a "compelling" governmental interest. Before exploring these particular implications of First Amendment protection of legislative voting, however, this Note briefly reviews the most recent and powerful application of the protection.

\section{CLARKE V. UNTED STATES: LegisLATIVE VOTING AS "NEW TERRITORY" FOR THE FIRST AMENDMENT}

The full D.C. Circuit ultimately vacated the three-judge panel's holding in Clarke v. United States because the appropriations statute that it invalidated lapsed prior to the full court's rehearing of the case. Nonetheless, Judge Edwards' initial decision still provides a useful analytic framework for under-

51. For an example of unprotected illegal activity, see United States v. Brewster, 408 U.S. 501 (1972) (receipt of money in exchange for Senator's vote and his promise to vote in certain way was not within sphere of legitimate legislative activity); see also Justice Black's concurrence in Tenney v. Brandhove, 341 U.S. 367, 379 (1951) (Black, J., concurring).

52. Tenney, 341 U.S. at 376: see also Hutchinson v. Proxmire, 443 U.S. 111 (1979) (Sptech or Debate Clause does not protect members of Congress from liability for transmittal of information in press releases or newsletters).

53. Parker v. Merlino, 646 F.2d 848 (3d Cir. 1981). Time limitations on floor debates and speeches serve a dual function. First, they facilitate decision by setting a definite cut-off point for discussion. Second, they promote rich discourse in the legislature by assuring that individual legislators or particular issues do not completely dominate to the exclusion of others.

54. Davids v. Akers, 549 F.2d 120 (9th Cir. 1977). Internal legislative procedures in Darids and Parker that restrict legislative voting are distinguishable from congressionally-imposed restrictions on legislative voting and do not warrant judicial scrutiny. Even if subject to First Amendment analysis, the need to dispense with legislative business meets the compelling-government-interest standard required under strict First Amendment scrutiny. Internal rules restricting expression do not of fend notions of popular sovereignty, but rather promote majoritarianism. 
standing how federal conditional spending implicates the First Amendment. ${ }^{5 s}$ Prior to vacatur, Clarke v. United States had invalidated the Armstrong Amendment to the 1989 D.C. Appropriations Act. ${ }^{56}$ The Armstrong Amendment conditioned the entire District of Columbia budget on the District government's adoption of an exemption to the District of Columbia Human Rights Law. ${ }^{57}$ The exemption specifically permitted religious organizations to deny any services or benefits to homosexuals. ${ }^{58}$ The court determined that when Congress exercises its "near-plenary authority" to create institutions of government for the District and to define their responsibilities, ${ }^{59}$ it must " "not contravene any provision of the Constitution." "60 Judge Edwards characterized the Armstrong Amendment as an unconstitutional condition and noted that " $[t]$ his limitation on Congress' powers is merely an instance of the general principle that the Government may not disregard the strictures of the Constitution when conferring discretionary benefits." 61 As a result, so long as the representative form of government established by the Home Rule Act in 1974 remains effective, ${ }^{62}$ Congress must respect the " "wide[] latitude' that the First Amendment guarantees the [District's City] Council members as legislators 'to express their views on issues of policy,'63 ... including their 'right to vote freely on issues as they arise." "64 Because the Armstrong Amendment "coerces" Council members to vote for particular legislation and because the interests asserted by the United States ${ }^{65}$ could not justify the abridgment of Council members' First Amendment rights, the court found the Armstrong Amendment to be unconstitutional. ${ }^{66}$ Specifically, the court applied the First Amendment test set forth in United

55. Clarke v. United States, 886 F.2d 404 (D.C. Cir. 1989), vacated as moot, 915 F.2d 699 (D.C. Cir. 1990) (en banc). (1988).

56. District of Columbia Appropriations Act, 1989, Pub. L. No. 100-462, § 145, 102 Stat. 2269-14

57. D.C. CODE ANN. $\$ 1-2501$ to 1-2557 (1981).

58. The Armstrong Amendment was a response to a local District of Columbia appellate court's holding that a section of the D.C. Human Rights Law, D.C. CODE ANN. \$ 1-2520 (1981), amended by Pub. L. No. 101-168, \$ 141, 1989 U.S.C.C.A.N. (103 Stat.) 1284, required Georgetown University to provide two student gay-rights groups equal access to university facilities and services. Gay Rights Coalition v. Georgetown Univ., 536 A.2d 1 (D.C. 1987) (en banc).

59. Clarke, 886 F.2d at 406 (citing U.S. CONST. art. I, \& 8, cl. 17).

60. Id. at 410 (quoting Palmore v. United States, 411 U.S. 389, 397 (1973)).

61. Id.

62. District of Columbia Self-Government and Governmental Reorganization Act, Pub. L. No. 93-198, 87 Stat. 774 (1973) (codified, in part, as amended, in scattered sections of 2, 5, 29, 31,40 U.S.C. (1989)).

63. Clarke, 886 F.2d at 417 (quoting Bond v. Floyd, 385 U.S. 116, 136 (1966)).

64. Id. (quoting Miller v. Town of Hull, 878 F.2d 523, 532-33 (Ist Cir.), cert. denied, 110 S. Ct. 501 (1989)).

65. The United States claimed two interests, both of which were rejected as insufficient to justify the restriction of expression. First, conditioning District funds on legislative action by the Council allowed the Senate to secure an amendment to the D.C. Code without violating the prohibition on "general legislation" in appropriations bills contained in Senate Rule XVI, para. 4. Second, the United States claimed an interest in compelling the Council to enact the required legislation itself in order to maximize "subsequent local control," because when the coercive conditions of the Armstrong Amendment expired, the Council would be free to repeal the once-required legislation; whereas, if Congress enacted the amendments directly, no opportunity for repeal by the Council would exist. Clarke, 886 F.2d at 414-15.

66. Id. at 417 . 
States $v . O^{\prime} B r i e n,{ }^{67}$ which requires that a general regulation of conduct that incidentally abridges speech " 'furthers an important or substantial . . . interest" and imposes 'no greater [a restriction of speech] than is essential to the furtherance of that interest ....'" Using this standard of review, the court found insufficient the government's asserted interest in restricting Council members' right to free expression through voting. ${ }^{68}$

Although one judge on the D.C. Circuit panel concluded that the court's conclusion seemed "compelled" by Supreme Court precedent, ${ }^{69}$ he also recognized that the decision opened up a substantial "new territory" of constitutional law. ${ }^{70}$ First, the opinion boldly reconceptualized the legal status of the statutorily-created District government by affording members of the District City Council a constitutional position equal to that of other local and state legislators. ${ }^{71}$ While the court's analogy between the District Council members and other local legislators raises interesting questions about the constitutional status of the District, this Note focuses on the court's unique interpretation of the First Amendment. Before Clarke, no legislator had ever attempted to employ the First Amendment to invalidate an act of Congress as restrictive of her free expression rights. Undeterred by the fact that its decision might implicate "political questions,"72 the court discovered a potential First Amendment limitation on Congress' use of conditional spending to legislate vicariously for the District of Columbia. This Note argues that the same limitation might also apply to conditional spending measures that inhibit the independent legislative voting of elected state and local representatives.

67. 391 U.S. 367 (1968) (upholding conviction under statute prohibiting burning draft cards, even though statute might incidentally abridge free expression, because government demonstrated substantial interest unrelated to suppression of free expression). Incidentally, the Clarke court suggested that a strict scrutiny evaluation of the Armstrong Amendment as a content-based regulation of speech might be appropriate. 886 F.2d at 413 (relying on Perry Educ. Ass'n v. Perry Local Educators Ass'n, 460 U.S. 37, 45 (1983)). The appropriate level of scrutiny to apply to restrictions on legislative voting is discussed in more detail below. See infra text accompanying notes 110-13.

68. Clarke, 886 F.2d at 413 (quoting United States v. O'Brien, 391 U.S. 367, 377 (1968)).

69. Id. at 417 (Buckley, J., concurring).

70. Id. at 418 .

At what point, for example, does a federal grant-in-aid program cross the line that separates the encouragement of state or municipal action from its coercion? Are the constitutional rights of corporate directors and university trustees comparable to those of state and municipal legislators? And when (if ever) is a particular government interest important enough to justify any burden on legislative speech?

Id.: see also Clarke v. United States, 915 F.2d 699, 708 (D.C. Cir. 1990), vacating as moot, 886 F.2d 404 (D.C. Cir. 1989).

71. Clarke found that "members of the Council are 'legislators' in every traditional sense." 886 F.2d at 410. Prior to Clarke, judicial understanding of the District's status rejected any notion of local sovereignty for its citizens: "[W] hile the District [is] 'a separate political community,' its sovereign power [is] lodged in the Congress." District of Columbia v. John R. Thompson Co., 346 U.S. 100, 107 (1953) (quoting Metropolitan R.R. Co. v. District of Columbia, 132 U.S. 1, 9 (1889)).

72. See infra notes $80-82$ and accompanying text. 
III. BEYOND CLARKE: APPLYING FirST AMENDMENT SCRUTINY to FEDERAL CONDITIONAL SPENDING MEASURES

The First Amendment rationale for limiting Congress' use of conditional spending measures in the District of Columbia suggests limiting the use of such measures outside the nation's capital as well. Thus, First Amendment protection of legislative voting should limit the federal government's use of conditional spending to dictate policy to states and localities. In the absence of a First Amendment argument similar to the approach taken in Clarke, challenges to federal conditional spending measures would necessarily raise vexing political questions about the proper limitation of federal influence over state and local policymaking. Now these issues can be raised in justiciable First Amendment claims. In some instances, application of the First Amendment would deprive the federal government of the power to condition funding to states on state or local enactment of particular federal policies.

A. The First Amendment's Protection of Legislative Independence Alters the Distribution of Power Between the Federal Government and State and Local Legislators

First Amendment protection of legislative voting, as compared with protections available under traditional notions of legislative immunity, substantially strengthens the capacity of legislators to challenge threats to their legislative independence. As a result, state and local legislators could use the courts more vigorously to challenge conditions on federal spending.

While common law and constitutional legislative immunities generally preserve the representative character of a legislator's activities, reinforce the separation of powers, and buttress the safeguards of federalism, they do not shield legislators from subtle restraints on legislative independence such as conditional spending. Because conditional spending measures do not impose criminal or civil penalties on individual legislators, they do not infringe on the legislative immunity protected by the common law ${ }^{73}$ or by the Speech or Debate Clause. ${ }^{74}$ Yet conditioning federal funding on the adoption of prescribed legislation still can decisively influence state and local legislative voting.

Had it not been vacated, the D.C. Circuit's original decision in Clarke $v$. United States would have been the first federal decision to recognize the potentially distorting effect of conditional spending measures on independent legislative voting. As a result, Clarke also would have been the first decision to hold that the First Amendment limits the use of conditional spending to influence

73. See supra notes 27-34 and accompanying text.

74. See supra notes 13-26 and accompanying text. 
legislative voting. ${ }^{75} \mathrm{~A}$ First Amendment rule protecting legislative voting nominally would guarantee individual legislators the right to vote freely and, more fundamentally, promote the people's paramount interest in representative legislatures. Yet perhaps the most significant implication of such a rule would be a restructuring of the relationship between local, state, and national governmental entities in the federal system.

In Miller v. Town of Hull, for example, the First Circuit delineated the legal limits of the Town Board of Selectmen's control over the votes of the elected members of the town's Redevelopment Authority. ${ }^{76}$ The Miller court determined that the Board's removal of Redevelopment Authority members due to a disagreement over the Authority's decision to proceed with a housing project for the elderly violated the First Amendment. ${ }^{77}$ While not a conditional spending case, Miller demonstrated that the First Amendment can shield legislative voting when traditional notions of legislative immunity fail to protect the public interest in legislative independence. At the same time, Miller redefined the relationship between two governmental entities by demarcating a constitutional limit on the Hull Board of Selectmen's influence over the town's elected Redevelopment Authority. Similarly, Clarke's application of First Amendment protection to the District Council delineated the constitutional limit of one governmental entity's influence over another, i.e., Congress' influence over the legislative process of the District Council. ${ }^{78}$

The reasoning of Miller and Clarke, two First Amendment decisions laden with significant implications for the structural relationships between governmental entities, make the possibility of a First Amendment decision altering the relationship between a state and the national government plausible. Following the analysis of Clarke, a court could conceivably hold that the First Amendment limits Congress' power to use funding to coerce legislators into voting for certain legislation, even though such a holding would shift the balance of power in national policymaking away from the central government. ${ }^{79}$ Clarke's First Amendment analysis thus allows courts which evaluate federal conditional spending measures to avoid the vexing justiciability problems often involved in disputes over the distribution of political power among governmental institutions, both within states and between states and the federal government.

75. The Supreme Court has never directly addressed the question of whether the First Amendment limits Congress' power to use conditional spending to influence state and local legislative voting. However, the Court has found that conditioning federal benefits un individuals, refraining from speech triggers First Amendment scrutiny. See, e.g., Speiser v. Randall, 357 U.S. 513, 518-19 (1958) (discriminatory denial of tax exemption for engaging in speech is limitation on free speech).

76. $\$ 78$ F.2d 523 (1st Cir.), cert. denied, 110 S. Ct. 501 (1989).

77. Id. at 533 .

78. Clarke v. United States, 886 F.2d 404 (D.C. Cir. 1989), vacated as moot, 915 F.2d 699 (D.C. Cir. 1990) (en banc).

79. The cumulative effects of such a limitation on federal conditional spending would depend upon precisely which and how many federal conditions are disallowed. Certainly, if a particular conditional spending measure is invalidated on First Amendment grounds, Congress could seek to achieve the same or similar ends through direct legislation under its enumerated powers. 


\section{B. Adjudicatory Reach of the First Amendment}

Before Clarke's application of the First Amendment to legislative voting, a legislator seeking judicial relief from the constraints of federal spending conditions would probably have raised questions that courts were either unwilling or unable to answer. These other challenges to federal spending measures would falter because they raised nonjusticiable questions. In contrast, the First Amendment approach, as applied in Clarke, promises to address congressional threats to state and local legislative independence more effectively than other constitutional principles.

The Guarantee Clause, which is one possible avenue for challenging restrictions on state and local legislative autonomy, necessarily implicates nonjusticiable political questions. ${ }^{80}$ The Ninth and Tenth Amendments could also form bases for constitutional challenges to federally imposed restrictions on independent legislative voting. Such an approach would inevitably require claimants to ask courts to resolve nonjusticiable questions about the unenumerated rights of the people and the extent of state autonomy guaranteed by these often overlooked constitutional provisions. ${ }^{81}$ Not suffering from these difficulties, the First Amendment approach is more likely to protect independent state legislative voting than the available alternatives. ${ }^{82}$

While the First Amendment may be superior to the alternatives in terms of justiciability, it is unclear whether courts can devise a judicially cognizable First Amendment test appropriate for resolving disputes between state and local legislators and Congress. Moreover, although judicial precedent demonstrates that the First Amendment's protections reach legislators when they speak in the course of discharging their legislative duties, it is not clear whether legisla-

80. U.S. CONST. art. TV, § 4 ("The United States shall guarantee to every State in this Union a Republican Form of Government ...."). The protection of independent legislative voting in the states would seem to fit under the Guarantee Clause of the U.S. Constitution. However, the Clause has been viewed as nonjusticiable in a wide variety of cases beginning with Luther v. Borden, 48 U.S. (7 How.) 1 (I849). But cf. Thomas C. Berg, Comment, The Guarantee of Republican Government: Proposals for Judicial Review, 54 U. CHI. L. REv. 208 (1987) (arguing for judicial review under the Guarantee Clause).

81. For discussion of the Ninth Amendment's nonjusticiability, see Lawrence G. Sager, You Can Raise the First, Hide Behind the Fourth, and Plead the Fifth. But What On Earth Can You Do With the Ninth Amendment?, 64 CHI.-KENT L. REV. 239, 251-52 (1988). As for judicial treatment of the Tenth Amendment, the Supreme Court's decision in Garcia v. San Antonio Metropolitan Transit Authority, 469 U.S. 528 (1985), effectively removes the courts from the process of determining the proper distribution of power between federal and state governments. Specifically, the Court concluded that the judiciary lacks the power "to employ freestanding conceptions of state sovereignty when measuring congressional authority under the Commerce Clause." Id. at 550. See generally JESSE H. CHOPER, JUDICIAL REVIEW AND THE NATIONAL POLITICAL PROCESS 175-259 (1980) (arguing that political branches, not federal judiciary, should decide constitutional questions of national government's power vis-a-vis the states).

82. Assuming that challenges to federal conditional spending measures under the Guarantee Clause, Ninth Amendment, and Tenth Amendment are nonjusticiable, a challenge to those same measures under the First Amendment's protection of legislative voting could still proceed. Since First Amendment claims are "not so enmeshed with those political question elements which render [the] Guarant[ee] Clause" and federalism concerns nonjusticiable, courts should be able to resolve these matters. Baker v. Carr, 369 U.S. 186, 227 (1962). 
tive voting falls within the umbrella of expressive conduct shielded by the First Amendment. The remainder of this Note addresses these questions and concludes that all federal conditional spending measures that impede independent state or local legislative voting necessarily trigger First Amendment scrutiny.

\section{The First Amendment and State Legislators: A First Amendment Test for Federal Conditional Spending Measures}

The three federal opinions declaring that First Amendment protection extends to legislative voting rely prominently on Bond v. Floyd, the first case to propose that the First Amendment protects "legislative speech." ${ }^{33}$ As a result, an understanding of Bond is critical to this Note's analysis.

Julian Bond, a Black man elected to the Georgia House of Representatives, was denied his seat in that assembly allegedly due to statements he made in opposition to the United States' military involvement in Vietnam. The Court held that the Georgia Legislature's refusal to seat Bond infringed upon his right of free expression under the First Amendment. ${ }^{84}$ Anchored in the ideology of republican government, ${ }^{85}$ the Court's opinion in Bond linked First Amendment safeguards of expression to the underlying values of representative government. The Court declared that legislators have "an obligation to take positions on controversial political questions so that their constituents can be fully informed by them, and be better able to assess their qualifications for office."86

The Bond Court did not, however, indicate whether or not voting falls within the scope of protected legislative speech. Similarly, while it highlighted the paramount importance of uninhibited local legislative speech for democratic government and set forth a tangible standard to protect such speech, ${ }^{87}$ Bond did not provide a test for evaluating restrictions on legislative voting. ${ }^{88}$

Such a test, however, is not difficult to conceive. It requires consideration of three questions. First, does vote casting in a legislative context constitute expressive conduct permitting legislators to invoke a First Amendment challenge to conditional spending measures? Second, at what point does a particular funding condition "restrict" free expression? Third, what level of First Amendment scrutiny should apply?

83. Bond v. Floyd, 385 U.S. 116 (1966).

84. Id. at 137.

85. The Court noted that constituents have an interest in a legislator's ability to take positions on controversial political questions "so they may be represented in governmental debates by the person they have elected to represent them." Id. at 136-37.

86. Id. at 136.

87. Id. at 135-37.

88. But see id. at 132 . The Court drew a distinction between permissible content-based regulations of legislative speech (e.g., constitutional provisions requiring legislators to take an oath swearing to uphold the Constitution) and impermissible "sham" rules (e.g., a rule authorizing a majority of state legislators to arbitrarily test the "sincerity" with which another duly elected legislator swears to uphold the Constitution). 
As a preliminary matter, a court should not have difficulty finding that legislative voting constitutes expressive conduct. Legislative voting is conducted with expressive intent and effect. Specifically, it conveys a particularized political message critical to a properly functioning representative democracy.

The response to the second question is more difficult to conceptualize. Like statutes in other "unconstitutional conditions" cases, the conditional funding measures on which this Note focuses are not laws that prohibit the exercise of the right of free expression. Rather, they can be seen as "inducing" or "coercing" its waiver or non-exercise. In recognition of the ambiguities inherent in identifying coercion or inducement, this Note borrows from recent scholarship that reformulates the "coercion test" as a requirement that conditional spending measures not upset the balance of power between beneficiaries of individual rights and the government. Under this framework, it seems clear that nearly all spending measures offering state governments financial benefits in exchange for particular legislative enactments will trigger First Amendment scrutiny. Conditional spending measures alter the balance of power between a state legislator and the federal government by restricting the legislator's ability to participate in and respond to public debate honestly and uninhibitedly. Thus, edicts of the federal government effectively replace policies generated by public discourse and debate among the people.

The answer to the third question involves issues of jurisdiction and intention. Where conditional spending measures compel state legislators to exercise the will of Congress in areas beyond Congress' constitutionally prescribed jurisdiction, those measures should be subject to the relaxed "incidental abridgment" of expression standard set forth in United States v. O'Brien. ${ }^{89}$ On the other hand, when Congress passes conditional spending measures designed to result in state legislators carrying out Congress' will in policy areas over which Congress could exercise direct control, those conditions should be subject to the strict level of scrutiny appropriate for content-based regulations of expression. ${ }^{90}$

89. 391 U.S. 367,377 (1968). Scrutiny in "incidental abridgment" cases generally requires a regulation of expression to advance a "substantial" government interest, and to be the least restrictive means available to the government for advancing that interest.

90. Strict scrutiny generally requires that a regulation of expression advances a "compelling" government interest and is "narrowly drawn" to achieve that end. $l d$. 


\section{Applying the New Test: Evaluating Conditional Federal Spending Measures Under the First Amendment}

This section examines in more detail the three components of the proposed First Amendment test for federal conditional spending measures. It concludes that all federal spending conditioned on state legislative enactments should trigger First Amendment scrutiny, but that the level of scrutiny applied should depend upon whether or not Congress has the power to enact the desired legislation directly.

\section{Legislative Voting As Nonfungible Expressive Conduct}

The Clarke court identified legislative voting as expressive conduct. According to the court, "[a] legislator's vote is inherently expressive." ${ }^{\text {"91 }} \mathrm{A}$ legislator's vote goes beyond the merely "mechanical" function of disposing with proposed legislation. It registers the " "“will, preference, or choice" of an individual legislator. "'92 Drawing upon language used by the Supreme Court in the flag-burning case, Texas v. Johnson, ${ }^{93}$ to determine whether certain forms of conduct constitute expression, the Clarke court stated that the vote of a legislator is protected expression because it is intended to "convey a particularized message" which will be understood by constituents and other observers. ${ }^{94}$

This view accurately reflects the reality of legislative voting. While legislators have a variety of mechanisms for transmitting their opinions to others, only a vote discharges an expression of opinion with finality and in unquestionable agreement with colleagues voting the same way. Moreover, because each vote is an individual expression of opinion, the independence of each vote constitutes the foundation of authentic representation.

Another look at the D.C. Council members' response to the Armstrong Amendment illustrates the uniquely expressive quality of legislative voting vis$\grave{a}$-vis other legislative activities. Presumably, individual Council members could have voted for the legislation prescribed by the Armstrong Amendment and simultaneously voted for a nonbinding resolution criticizing both the legislation and Congress for compelling their votes in favor of the legislation. On the one hand, such a resolution would express opposition to the legislation. On the other hand, voting for such nonbinding language would express an idea distinct from a vote against the actual amendment. While a vote for the nonbinding resolution

91. Clarke v. United States, 886 F.2d 404, 411 (D.C. Cir. 1989), vacated as moot, 915 F.2d 699 (D.C. Cir. 1990) (en banc).

92. Id. at 411 (quoting Montero v. Meyer, 861 F.2d 603, 607 (10th Cir. 1988) (quoting BLACK's LAW DICTIONARY 1414 (5th ed. 1979)), cert. denied, 492 U.S. 921 (1989)).

93. 491 U.S. 397 (1989).

94. Clarke, 886 F.2d at 412 (quoting Texas v. Johnson, 491 U.S. at 404 (quoting Spence v. Washington, 418 U.S. 405, 410-11 (1974))). 
would express limited opposition, a vote against the actual legislation would express a refusal, on the part of the individual legislator, to support the use of resources or the employment of force to further the policy. Although if compared, these two legislative votes would not reflect a sharp difference of opinion, they would certainly convey a difference in the intensity of opinion.

The same could be said for the votes of members of the Hull Redevelopment Authority whose removal for their continued support of a housing project for the elderly was at issue in Miller $v$. Town of Hull. ${ }^{95}$ While a nonbinding resolution would have also expressed opposition to the Board's development plans, the vote for the housing project was a stronger statement in favor of a positive commitment of resources to support the project. A vote for legislation and a vote for a nonbinding resolution each reflects a distinct value judgment by the legislator, and each is uniquely expressive despite the identical subject matter. ${ }^{96}$

Similarly, in Texas v. Johnson, Gregory Lee Johnson may have had alternative means to express outrage at the policies of the U.S. Government; yet, none of these alternatives could have captured the intensity of outrage and defiance that burning the national symbol expressed. ${ }^{97}$ Voting, like flag burning, is a nonfungible, expressive act. Statements and other votes may amend or alter a legislator's political position, but each vote has an expressive quality indelibly etched into the legislator's record.

\section{Clearing Up Coercion: A Structural Approach to Addressing Unconstitutional Conditions and Restrictions on Legislative Voting}

Concerned about the unrestrained power of Congress to regulate individual and state governmental activity through the funding mechanism, courts and commentators have searched for limits. The doctrine of "unconstitutional conditions" emerged from this search. Courts frequently apply this constitutional limitation on conditional spending through the application of the "coercion test." The "coercion test" essentially prohibits conditions that induce beneficiaries of federal government spending to waive inalienable constitutional guaran-

95. 878 F.2d 523 (1st Cir.), cert. denied, 110 S. Ct. 509 (1989).

96. One serious objection to characterizing legislative voting as expressive conduct suggests that it is quintessential "governance" unprotected by the First Amendment. Spallone v. United States, 110 S. Ct. 625, 646 n.12 (1990) (Brennan, J., dissenting). This objection, however, fails to make a critical distinction between the act of casting a legislative vote, which is an individual's expression that alone has no coercive effect, with government action authorized by the full body of the legislature. The fact that individual legislators often vote in the minority and do not prevail on a particular question before the chamber illustrates this distinction. Certainly, these minority votes do not themselves constitute government action. Similarly, a great many legislative votes never result in government action due to legislative bicameralism and executive veto. A rebuttal might assert, however, that conditional spending targets government action and not individual legislative votes. However, even assuming that one could satisfactorily demonstrate such a motive, First Amendment scrutiny still applies because, against the background of democratic state legislatures, conditional spending necessarily contemplates a direct impact on the votes of individual legislators.

97. 491 U.S. at 404-05 (1989) (discussing unique "communicative nature of conduct relating to flags"). 
tees in order to receive government benefits. ${ }^{98}$ The Supreme Court derived this test by construing individual rights provisions in the Constitution as limiting Congress' power to attach conditions when supplying government benefits to individuals. ${ }^{99}$ Specifically, the Supreme Court has held that the First Amendment rights of individuals provide such a constitutional bar to conditional federal spending. ${ }^{100}$ In contrast, when states argue that conditions attached to federal grants for state governments violate the Tenth Amendment and other constitutional provisions, the Court has been unwilling to read a limitation on Congress' spending power into these provisions. ${ }^{101}$

By asserting that "the Armstrong Amendment coerces the Council members' votes on a particular piece of legislation," 102 the Clarke court may have broken the deadlock on constitutional challenges to federal spending conditions applied to states and localities. Clarke's analytic contribution is that, for the first time in an unconstitutional conditions case, a federal court shifted the judicial focus from the condition's effect on state and local governmental autonomy and from nonjusticiable federalism questions to a more concrete individual rights formulation. In spite of this innovation, however, the Clarke court remained mired in the analytic ambiguities of the coercion test.

Indeed, Clarke's application of the coercion test raised more questions than it answered. At what point does such coercion occur? Must it be, as in Clarke, that release of the entire governmental budget is conditioned upon a particular legislative act? Is it necessary that the salaries of legislators be at stake? ${ }^{103}$

98. "Coercion" is interchangeable with "inducement" in the courts and for the purposes of this Note. Another set of unconstitutional conditions cases has required a showing of "germaneness" or relatedness of the condition to the purposes of the funding provision. See, e.g., Nollan v. California Coastal Comm'n, 483 U.S. 825 (1987) (conditioning building permit on granting of public access easement by property owners was unrelated to purpose for which building in question might have been banned).

99. Congress has the power to "provide for the common Defence and general Welfare of the United States." U.S. CONST. art. I, \$ 8, cl. 1 .

100. See, e.g., FCC v. League of Women Voters, 468 U.S. 364, 402 (1984) (invalidating condition denying federal public broadcasting funds to stations engaging in editorializing); Speiser v. Randall, 357 U.S. 513, 518-19 (1958) (holding state requirement that veterans take loyalty oath before receiving property tax exemption violates First Amendment).

101. In South Dakota v. Dole, 483 U.S. 203 (1987), for example, several states challenged conditioning a portion of federal grants to states designated for the construction of interstate highways on states adoption of the national minimum drinking age. Part of the challenge focused on the Tenth Amendment's limitation on congressional regulation of state affairs. The Court found no infringement of state sovereignty because a state "could, and did, adopt 'the "simple expedient" of not yielding to what she urges is federal coercion." Id. at 210 (quoting Oklahoma v. Civil Serv. Comm'n, 330 U.S. 127, 143-44 (1947)). The states also argued that the Twenty-first Amendment bars the federal government from regulating the drinking age. The Court found that while the Twenty-first Amendment limits Congress' power to regulate directly the distribution of alcohol, "constitutional limitations on Congress when exercising its spending power are less exacting than those on its authority to regulate directly." Id. at 209 (citing United States v. Butler, 297 U.S. 1, 66 (1936)).

102. Clarke v. United States, 886 F.2d 404, 417 (D.C. Cir. 1989), vacated as moot, 915 F.2d 699 (D.C. Cir. 1990) (en banc).

103. Although this issue was not addressed by the Clarke court, the Armstrong Amendment, by conditioning the totality of the District government's budget, including expenditure of locally raised funds, also conditioned the appropriation of Council members' salaries. While a threat to the personal fiscal affairs of an individual legislator arguably may be the minimal threshold for triggering common law notions of 
The court did not attempt to explain its conclusion beyond stating that the threatened shutdown of municipal government "compelled" legislators to vote in favor of the proposed amendments. ${ }^{104}$ The court did not indicate what, if any, less severe consequences would amount to coercion. Clearly, if the principles in Clarke regarding the protection of independent legislative voting are to be taken seriously, courts must either develop a more generalized system for identifying coercion or find a substitute for the coercion test.

While it is beyond the scope of this Note to explain fully every new approach to identifying unconstitutional conditions, the Note does explain how application of the federalism and republicanism principles set forth in Sections $\mathrm{B}$ and $\mathrm{C}$ of Part I could have informed Clarke, and possibly other cases, without the ambiguities inherent in the coercion test.

The "structural" approach to unconstitutional conditions set forth in recent works provides a superior analytic framework to replace the coercion test. In particular, it provides a useful vehicle for evaluating federal statutes that condition funding for states on the enactment of federally prescribed legislation. Taking this approach, Professors Sullivan, ${ }^{105}$ Kreimer, ${ }^{106}$ and Rosenthal ${ }^{107}$ contend that unconstitutional conditions, no less than direct infringernents on liberties, can alter the "balance of power" between the government and rights holders in the federal system, and that the preservation of this balance is the gravamen of the validity of a condition. Their "structural" approach has two basic advantages over the ambiguous coercion test in explaining the constitutional infirmity of federal conditional spending measures.

First, by analyzing these measures under the structural approach, a court focuses on the constitutional values that are really at stake when the federal government conditions funding on state legislative enactments. Although these measures directly threaten the First Amendment rights only of individual legislators, those individual rights safeguard the entire polity's interest in a constitutional structure that relies on representative state legislatures as independent sources of political power.

The structural approach is better equipped to account for the polity's interest in independent state legislatures because it emphasizes the role of government and the effect of governmental policy on the balance of power in the federal system. Conditional spending measures that transfer political power in the form of free speech rights from individual state legislators to the federal government effectively cede the polity's constitutionally guaranteed right to

legislative immunity, such a threat is not necessary to trigger a First Amendment challenge to spending conditions.

104. Clarke, 886 F.2d at 409.

105. Kathleen M. Sullivan, Unconstitutional Conditions, 102 HARV. L. REV. 1413, 1489-1505 (19\$9).

106. Seth F. Kreimer, Allocational Sanctions: The Problem of Negative Rights in a Positive State, 132

U. PA. L. REV. 1293, 1382-95 (1984).

107. Albert J. Rosenthal, Conditional Federal Spending and the Constitution, 39 STAN. L. REV. 1103, 1105-06 (1987). 
representative government at the state level. In evaluating conditional spending measures under this rubric, courts can focus on the condition's actual effect on the balance of power between the federal government and state legislators and not on vague notions of coercion.

It is important to keep in mind, however, that the pertinent "balance of power" rests among those who have the power to speak as representatives of citizens on matters of public concern. In other words, through the election process, the people vest their state representatives with the First Amendment right to vote freely, as their agents or trustees, on issues of public concern. A federal spending condition that offers governmental benefits to a state in exchange for a particular legislative enactment effectively alienates the individual legislator from her right of expression through voting. This, in turn, alters the constitutionally prescribed balance of power by shifting independent voting power away from the state legislator and enhancing the power of the federal government. ${ }^{108}$

The second advantage to the structural approach, like the first, dispenses with the unnecessary ambiguities associated with the coercion test. In particular, the structural approach does not require a court to make the quasi-psychological finding that the government "coerced" a particular individual. Rather, the structural approach applies constitutional scrutiny to any federal attempt to condition funding on state legislative outcomes regardless of whether "coercion" is demonstrated. This scrutiny applies because certain constitutional liberties, while framed as individual rights, serve as structural constitutional counterbalances to federal power. If the federal government could induce the waiver of such counterbalancing rights, those rights would be worthless as safeguards against federal excess.

It follows that the First Amendment's protection of free expression generally, and of independent legislative voting in particular, is one such right that state legislators should not be permitted to waive and that the federal government should not be permitted to buy. As a cornerstone of authentic representation and federalism, the independent voting of state legislators is indispensable to checking potential excesses of the federal government. Furthermore, legislators, when offered government benefits in exchange for waiving their First Amendment rights to vote freely, might undervalue the constitutional and structural values those rights serve. ${ }^{109}$ Indeed, a legislator's right to vote freely is not a personal privilege that can be waived but, rather, an inalienable right

108. State autonomy may actually be infringed to a lesser degree by direct federal legislation, where the "political safeguards of federalism" shield states from federal excess, than when federal conditions are attached to important funding measures upon which states are vitally dependent. Rosenthal, supra note 107 , at 1141-42, 1162-63; Sullivan, supra note 105, at 1500-01 (citing South Dakota v. Dole, 483 U.S. 203 (1987), as an "easy case" for strict constitutional review).

109. Sullivan, supra note 105 , at 1491 . 
designed to protect the entire polity's interest in federalism and representative government.

A legislator's First Amendment right to vote uninhibitedly on issues of public concern serves the constitutional structural values of federalism and representation. A legislator holds as trustee a right that serves the entire polity's interest in constitutional government. Consequently, whether or not a particular federal statute that conditions funding for states on a prescribed state legislative enactment "coerces" legislative voting, such a statute implicates a First Amendment interest worthy of judicial protection.

\section{3. "Related To" Expression vs. "Incidental Abridgment"}

Having established that legislative voting is expressive conduct and that governmental attempts to influence state legislative enactments through conditional spending restrict legislative voting, it remains to be determined what level of First Amendment scrutiny courts should apply. In Clarke v. United States, the answer to this question appeared relatively clear. ${ }^{110}$ Since Congress could have enacted its amendments directly into the D.C. Human Rights Law, it could not show any substantial justification for the Armstrong Amendment other than the desire to have the City Council members enact the measure themselves. ${ }^{111}$ Thus, the court should have recognized the Armstrong Amendment as directly related to the suppression of free legislative voting and, as such, subject to strict First Amendment scrutiny. Similarly, in cases where Congress already has the constitutional authority to legislate directly but instead chooses to employ the conditional funding mechanism, courts should evaluate such measures as content-based suppressions of expression. Unless the government articulates a reason not related to the suppression of expression (i.e., Congress is able to legislate directly in a particular field, but the diversity of conditions among the states requires the flexibility of locally-devised versions of federal programs), strict scrutiny should apply. ${ }^{112}$

Another First Amendment problem arises where Congress does not already possess the power to legislate directly over a certain subject matter yet tries to impose its will through conditional spending designed to influence state legislation. At first blush, these measures seem more intrusive on state autonomy than when Congress uses a conditional spending measure to accomplish an end that could be constitutionally achieved with direct federal legislation. Ironically, this use of conditional spending does not warrant strict First Amendment scrutiny because the federal government can at least demonstrate a prima facie justification for the measure that is entirely unrelated to expression. If the federal government demonstrates that the Constitution prohibits direct congressional

110. 886 F.2d 404 (D.C. Cir. 1989), vacated as moot, 915 F.2d 699 (D.C. Cir. 1990) (en banc).

111. Id. at $413-15$.

112. See supra note 90. 
regulation of a particular field, then the conditional funding measure is a general regulation of conduct that only incidentally abridges expression. As such, the more relaxed "incidental abridgment" standard of scrutiny set forth in United States v. O'Brien should apply. ${ }^{113}$ To be sure, some infringement of legislative independence will occur, even if only incidentally. This is why the federal government must still demonstrate that the conditional funding mechanism is the least restrictive means available for the regulation to pass constitutional muster.

\section{CONCLUSION}

The First Amendment's protection of free expression is an essential mechanism providing for participation in democratic self-government by all members of society. Nowhere is this mechanism more important than in the realm of political decisionmaking. ${ }^{114}$ If the legitimacy of government is to be measured by the consent of the governed, uninhibited expressions of opinion must be permitted to facilitate the formation of both individual judgments and the common judgment.

Since Bond v. Floyd, legislators, like other members of society, have enjoyed the protections of free expression embodied in the First Amendment. Free expression in the legislature not only serves the deliberative process and allows voters to choose their representatives according to their expressed beliefs and opinions, it also reinforces the constitutional safeguards of federalism and the separation of powers.

As an expressive act that registers the will, preference, and opinion of a legislator, voting performs a unique communicative function. It expresses loyalty or dissension, agreement or abstention. It can also inform voters of a legislator's position on matters of public concern. Not only is legislative voting expressive, it is also representative and political, and therefore critical to the proper functioning of participatory democracy.

Recent judicial application of First Amendment protection to legislative voting may have opened the door for states and localities to challenge federal conditional spending measures on the ground that they restrict free expression. In terms of its practical effects on federalism, this protection may not lead to wholesale invalidation of the broad array of federal programs based on conditional spending, but, at a minimum, it should instruct federal lawmakers and courts to appreciate the vital role their more provincial counterparts perform in our system of freedom of expression.

113. 391 U.S. 367,377 (1968).

114. See generally Meyer v. Grant, 486 U.S. 414, 420-21 (1988); Boos v. Barry, 485 U.S. 312,318 (1988); Robert H. Bork, Neutral Principles and Some First Amendment Problems, 47 IND. L.J. 1 (1971). 
